\title{
RESPOSTA DA APLICAÇÃO DE SÍLICIO VIA SOLUÇÃO NUTRITIVA E PULVERIZAÇÃO EM PLANTAS DE AMENDOIM
}

\author{
Stefania Fernandes ${ }^{1}$; Renato de Mello Prado ${ }^{2}$; Gilmara Pereira da Silva ${ }^{3}$ \\ ${ }^{1}$ Graduanda em Engenharia Agronomica, FCAV/UNESP, Jaboticabal, SP, stefania1112fernandes@gmail.com; \\ ${ }^{2}$ Docente da FCAV/UNESP, Jaboticabal, SP; ${ }^{3}$ Pós Doutoranda em ciência do solo, FCAV/UNESP, Jaboticabal, \\ SP.
}

RESUMO: A cultura do amendoim é uma planta não acumuladora de Silício. Sendo assim, o objetivo do presente estudo foi observar a absorção de silício e o seu reflexo na matéria seca. O experimento foi realizado em casa de vegetação com delineamento casualizado, contendo cinco repetições, com quatro tratamentos, os quais foram: Zero Silício (controle), Silício via radicular, Silício via foliar e Silício radicular+Si via foliar. Observou-se a partir dos resultados, que o fornecimento de silício via solução nutritiva associado com a pulverização foliar promoveu maior teor de silício na parte aérea, porém, não se diferenciou do silício aplicado somente via solução nutritiva, mas ambos apresentaram maior teor de silício em relação ao controle. Portanto, o fornecimento de silício via solução mais pulverização foliar, semelhante ao fornecimento somente via radicular, promovem maior absorção de silício, refletindo em uma maior produção de matéria seca.

Palavras-chave: Arachis hypogaea L., elemento benéfico, adubação foliar.

\section{INTRODUÇÃO}

O amendoim (Arachis hypogaea L.) é originário da América do sul, pertence ao grupo das plantas fabáceas. Foi amplamente disseminado pelo mundo através dos portugueses. De acordo com a Companhia Nacional de Abastecimento - Conab - a área estimada de amendoim está em torno de 129,3 mil hectares, distribuídos entre as lavouras conduzidas neste novo padrão tecnológico (São Paulo, Rio Grande do Sul, Mato Grosso do Sul e Minas Gerais) e os pequenos cultivos familiares em diversos Estados do Norte e Nordeste (CONAB, 2017). A produção nacional de amendoim atingiu na safra 2016/2017 uma produção de 466,2 mil toneladas, sendo o estado de São Paulo o principal produtor, concentrando 90,6\% desta produção (CONAB, 2017).

Com a evolução das pesquisas na área de nutrição mineral de plantas, foram identificados alguns elementos que podem ser considerados benéfico para algumas espécies ou mesmo substituir parcialmente a função de elementos essenciais. Outros, quando em concentrações muito baixas, estimulam o crescimento de plantas, porém sua essencialidade não é demonstrada ou, apenas demonstrada sob determinadas condições especiais. Esses elementos têm sido classificados como elementos benéficos (EMBRAPA, 2007).

O silício ( $\mathrm{Si}$ ) é considerado elemento benéfico, sendo absorvido pelas plantas na forma de ácido monossilícico $\left[\mathrm{Si}(\mathrm{OH})_{4}\right]$ (EPSTEIN; BLOOM, 2006), como elemento benéfico, o silício pode 
promover inúmeros benefícios para as plantas, proporcionando aumento na produtividade da cultura (GOMES et al., 2011).

As plantas que absorvem silício podem ser classificadas em acumuladoras, como o arroz, sorgo e milho, pois em geral possuem teor foliar acima de 1\%, e não acumuladoras, a exemplo do feijão e da soja, plantas com teor de silício menor que $0,5 \%$ (MA et al., 2001). Sendo a cultura do amendoim também leguminosa, é uma planta não acumuladora de silício.

Diante do exposto, o presente trabalho teve como objetivo avaliar o desenvolvimento da cultura do amendoim até a floração, para obter dados relacionados à resposta da cultura quanto à aplicação de silício, e seus efeitos nos resultados de matéria seca.

\section{MATERIAL E MÉTODOS}

O trabalho foi realizado em casa de vegetação no Câmpus da Faculdade de Ciências Agrárias e Veterinárias-/UNESP, Jaboticabal, SP. O experimento foi conduzido no período de dezembro de 2017 á fevereiro de 2018. O delineamento estatístico utilizado foi de blocos casualizados, com cinco repetições e quatro tratamentos: Controle (-Si), Si via radicular ( $\mathrm{Si}$ R), Si via foliar ( $\mathrm{Si}$ F) e Si via radicular e foliar $(\mathrm{Si} \mathrm{R}+\mathrm{F})$. As sementes de amendoim utilizadas foram da cultivar Granoleico.

Cada unidade experimental foi formada por um vaso com capacidade para $7 \mathrm{dm}^{3}$, preenchidos com $6,5 \mathrm{dm}^{3}$ de areia lavanda. Foi usado a solução nutritiva proposta por Hoagland \& Arnon a uma concentração de $25 \%$ durante todo o desenvolvimento da cultura. A fonte de silício utilizada foi o silicato alcalino.

O tratamento zero silício (controle) foi mantido com solução nutritiva completa e sem uso do silício, o tratamento com silício via radicular foi realizado com solução nutritiva completa acrescida de silício na concentração de $2 \mathrm{mmol} / \mathrm{L}$, o tratamento com silício via foliar foi realizado com a pulverização com água deionizada e silício na concentração de $4 \mathrm{mmol} / \mathrm{L}$ uma vez a cada sete dia, e o tratamento com silício via radicular + silício via foliar foi com solução nutritiva completa acrescida de silício na concentração $2 \mathrm{mmol} / \mathrm{L}$ mais a aplicação foliar uma vez a cada sete dias na concentração de $4 \mathrm{mmol} / \mathrm{L}$. Os tratamentos que faziam uso das aplicações foliares de silício, as aplicações foram feitas a cada sete dias, iniciando a primeira pulverização foliar quinze dias após a germinação das plantas e acompanhando até o desmonte do experimento fazendo um total de cinco aplicações foliar de silício.

Para as avaliações foram arrancadas plantas de amendoim no estágio de floração com 45 dias após a germinação. Em seguida, as plantas foram lavadas conforme procedimento de laboratório e colocadas para secar em estufa a $60^{\circ} \mathrm{C}$ por três dias, depois de secas, determinou-se a massa seca e as plantas foram moídas e realizou-se a análise de silício com a mistura de duas metodologias, a digestão foi realizada seguindo o método de KRASKA \& BREITENBECK (2010) e leitura das amostras foi feita de acordo com o método amarelo obtendo o teor de silício, e com base no teor foi calculado a concentração de silício. 
Os resultados obtidos foram submetidos a analise de variância pelo teste $F(p<0,05)$ e as médias comparadas pelo teste de Tukey a $5 \%$ de probabilidade.

\section{RESULTADOS E DISCUSSÃO}

Comparando os tratamentos, observou-se diferença no teor de silício. O tratamento zero silício apresentou o menor valor de teor, o que já era esperado por não conter silício. A aplicação de silício via foliar, demonstrou valores intermediários, quando comparado com os tratamentos com silício foliar + silício via radicular e com o tratamento de silício via radicular, que obtiveram os maiores valores para o teor de silício quando comparados ao tratamento zero silício.

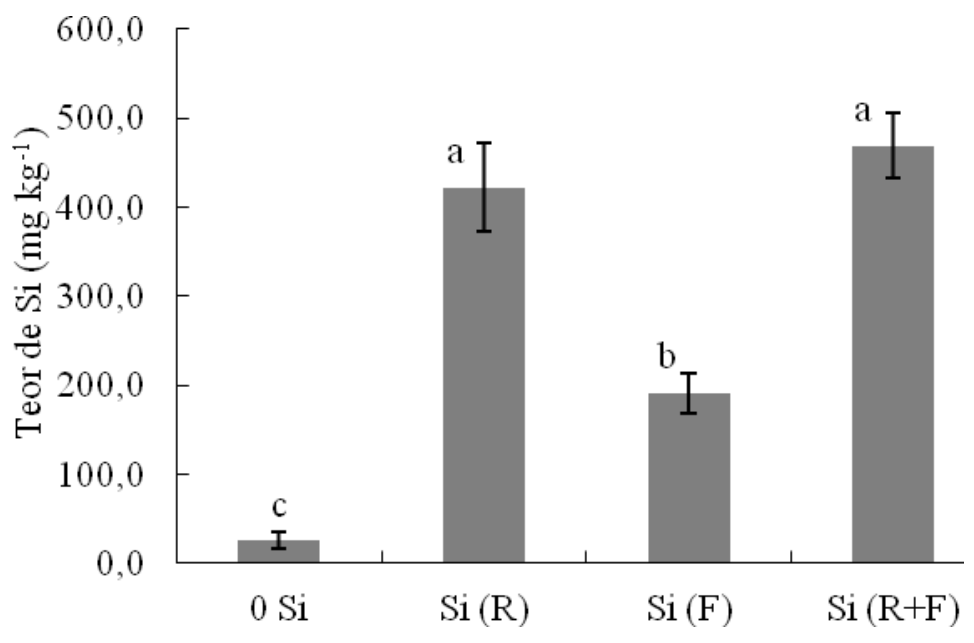

Figura 1. Teores de silício em plantas de amendoim da cultivar Granoleico.

Os dados relacionados ao acúmulo de silício nas plantas, também dito como a concentração de silício nas plantas, constatou maior acúmulo de silício nos tratamentos silício via foliar+ silício via radicular e silício via radicular quando comparados à testemunha zero silício, já o tratamento silício via foliar não diferiu da testemunha quanto ao acúmulo de silício. 


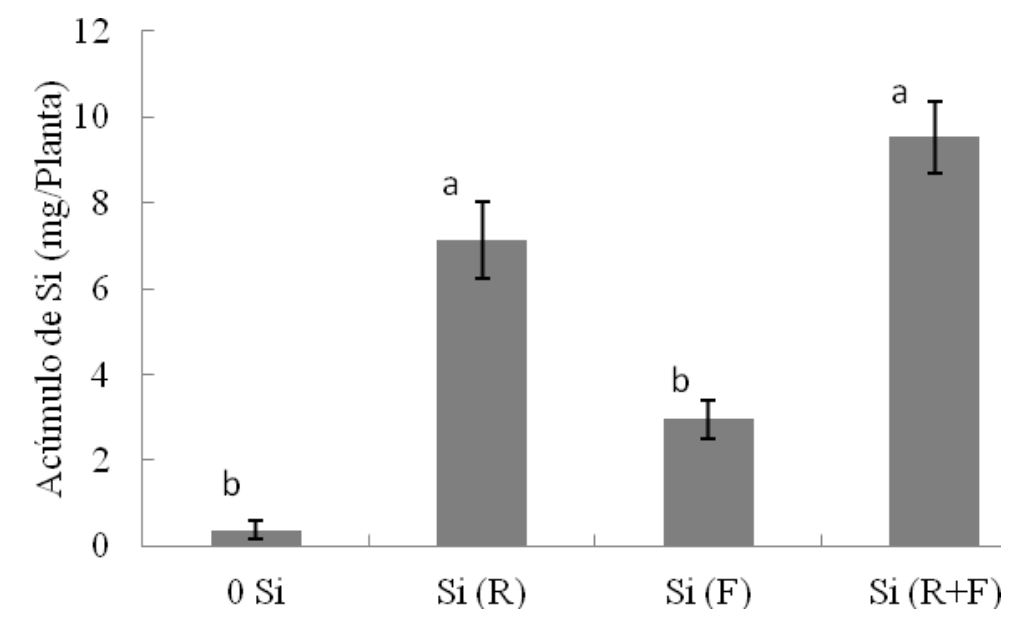

Figura 2. Acumulo de silício em plantas de amendoim da cultivar Granoleico.

Comparando os resultados de matéria seca, observou-se que, o tratamento de silício via foliar obteve os menores valores de matéria seca que não se difere da testemunha. Diante disso, o tratamento de silício via radicular + silício via foliar apresentou o maior valor de matéria seca, quando comparado à testemunha - zero silício-. O tratamento silício via radicular apresentou nos dados de matéria seca uma eficácia tão quanto a anterior, pois nesse tratamento foi concluído que o resultado é equivalente ao tratamento silício via radicular + silício via foliar, conquanto isso, não se diferir completamente do tratamento zero silício. Sendo assim, os melhores resultados de matéria seca foram os tratamentos de silício via foliar + silício via radicular e o de silício via radicular.

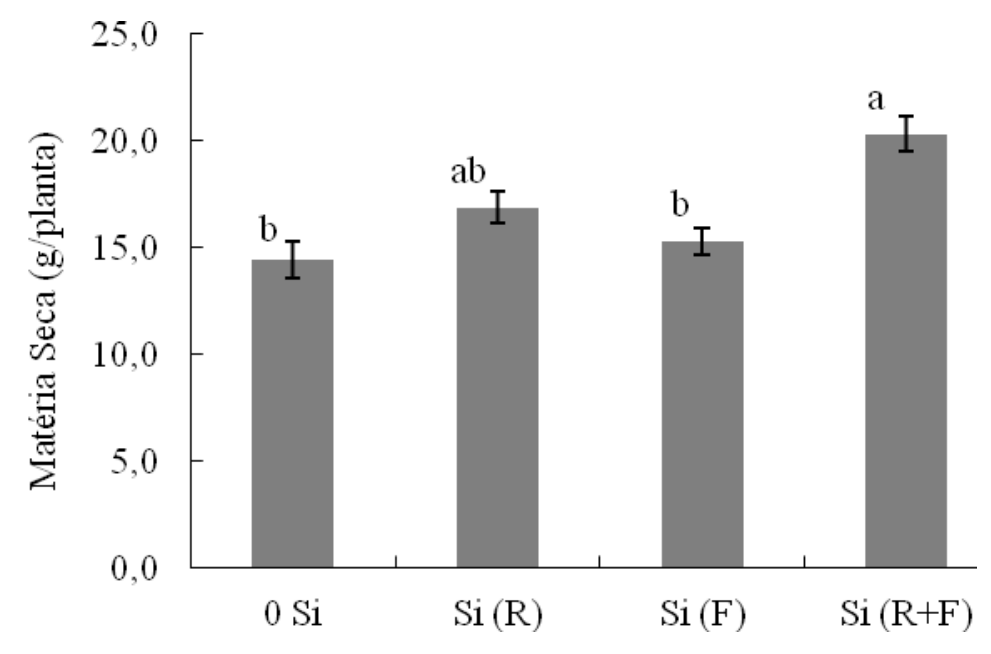

Figura 3. Matéria seca em plantas de amendoim da cultivar Granoleico.

A partir dos resultados, foi constatado que a aplicação de silício realmente promove aumento de matéria seca, conforme a hipótese inicial. E de acordo com dados encontrados na literatura, o silício pode promover inúmeros benefícios para as plantas, proporcionando aumento da matéria seca 
16 e 17 de agosto de 2018, centro de convenções da FCAV/UNESP - Câmpus de Jaboticabal, SP

(GOMES et al., 2011), benefícios esses que são relacionados à amenização de estresses ocasionados por fatores abióticos (secas, geadas e altas temperaturas) (EPSTEIN, 1999).

Portanto, a maneira mais eficiente de obter esse resultado benéfico do silício na cultura do amendoim é a aplicação de silício conforme os tratamentos silício via radicular + silício via foliar ou silício via radicular.

\section{CONCLUSÃO}

O silício promove maior produção de matéria seca em amendoim, destacando a aplicação de silício via radicular mais a pulverização foliar, análogo a aplicação de silício via radicular promovendo maior absorção de silício (teor) e acúmulo de silício, consequentemente, refletindo em uma maior produção de matéria seca.

\section{AGRADECIMENTOS}

Os autores prestam seus agradecimentos à Faculdade de Ciências Agrárias e VeterinárioUNESP - Câmpus de Jaboticabal, por propiciar o desenvolvimento do trabalho.

\section{REFERENCIAS BIBLIOGRÁFICAS}

CONAB. Companhia Nacional de Abastecimento. Produção de amendoim. Disponíve lem: http://www.conab.gov.br/. Acesso em: 20 de julho de 2018.

EMBRAPA. Empresa Brasileira de Pesquisa Agropecuária. Introdução a fertilidade do solo. Disponível em: https://ainfo.cnptia.embrapa.br/. Acesso em: 20 de julho de 2018.

EPSTEIN, E. Silicon. Annual Review of Plant Physiology and Molecular Biology, Palo Alto, v. 50, p. 641-664. 1999. Disponível em: <https://doi.org/10.1146/annurev.arplant.50.1.641>

EPSTEIN, E.; BLOOM, A.J. Nutrição mineral de plantas: princípios e perspectivas. Londrina: Planta, 2006. p.71-84.

KRASKA, J. E.; BREITENBECK, G. A. Simple, robust method for quantifying silicon in plant tissue. Communications in Soil Science and Plant Analysis, v.41, n.17, p.2075-2085, 2010.

GOMES, C. F.; MARChETti, M. E.; NOVElinO, J. O.; MAUAD, M.; AlOVISI, A. M. T. Disponibilidade de silício para a cultura do arroz, em função de fontes, tempo de incubação e classes de solo. Pesquisa Agropecuária Tropical, v. 41, p. 531-538, 2011.

MA, J. F.; MIYAKE, Y.; TAKAHASHI, E. Silicon as a beneficial element for crop plant. In: Silicon in Agriculture. Edited by DATNOFF, L. E., KORNDÖRFER, G. H., SNYDER, G. New York: Elsevier science. 2001. p. 17-39. 